\title{
Efektivitas Isolat Bakteri dari Rizosfer dan Bahan Organik Terhadap Ralstonia solanacearum dan Fusarium oxysporum pada Tanaman Kentang
}

\author{
Effectiveness of Bacterial Isolates from Several Rhizospheres and \\ Organic Materials against Ralstonia solanacearum and \\ Fusarium oxysporum on Potato
}

Tutik Kuswinanti*, Baharuddin, Sri Sukmawati

Universitas Hasanuddin, Makasar 90245

\begin{abstract}
ABSTRAK
Rizosfer merupakan daerah yang ideal untuk pertumbuhan dan perkembangan mikrob antagonis. Nutrisi yang disekresikan tanaman ke dalam rizosfer banyak dipengaruhi oleh faktor lingkungan dan selanjutnya mempengaruhi kelimpahan dan keragaman mikrob di daerah tersebut. Penelitian ini bertujuan untuk mengisolasi bakteri dari rhizosfer tanaman dan dari bahan organik di Tana Toraja, dan menguji potensi bakteri tersebut sebagai agens hayati penyakit layu kentang. Sampel tanah diambil dari rizosfer tanaman padi, bambu, kentang, dan terung belanda; serta dari bahan organik kerbau belang dan babi. Uji antagonisme isolasi, Ralstonia solanacearum dan Fusarium oxysporum dilakukan untuk mengetahui kemampuan daya hambat masing-masing isolat bakteri dengan metode biakan ganda serta tahapan identifikasi. Hasil penelitian menunjukkan bahwa dari total 74 isolat bakteri, terdapat berturutturut $10 \mathrm{dn} 4$ isolat bakteri yang mampu menghambat pertumbuhan $R$. solanacearum dan $F$. oxysporum secara in vitro.
\end{abstract}

Kata kunci: antagonis, penghambatan, penyakit layu

\begin{abstract}
Rhizosphere is an ideal area for growth and development of microbial antagonists, because it is a nutrition rich area. Nutrients that secreted in the rhizosphere are influenced by many environmental factors which in turn effect the diversity and abundance of microbial community. Based on these facts, the research were aimed to isolate bacteria from the rhizosphere and organic materials in Tana Toraja, and determine their role as biological control agents for potato wilt disease. Antagonistic test was conducted in order to determine the ability of each bacterial isolate to inhibit the growth of Ralstonia solanacearum and Fusarium oxysporum. The results showed that from totally 74 bacterial isolates, only 10 and 4 bacterial isolates were able to inhibit the growth of $R$. solanacearum and F. oxysporum in vitro, respectively.
\end{abstract}

Key words: antagonist, inhibition, potato wilt

*Alamat korespondensi penulis: Jurusan Hama dan Penyakit Tumbuhan, Fakultas Pertanian, Universitas Hasanuddin Jalan Perintis Kemerdekaan Km. 10, Makassar 90245

Tel: 0411-587100, Faks: 0411-587100, Surel: koeswinanti@yahoo.com 


\section{PENDAHULUAN}

Rendahnya produktivitas kentang di Indonesia disebabkan oleh teknik budi daya yang belum optimal, kurangnya ketersediaan bibit yang bermutu dan bersertifikat, serta serangan organisme pengganggu tanaman. Salah satu penyakit pada kentang adalah penyakit layu yang disebabkan bakteri Ralstonia solanacearum dan cendawan Fusarium oxysporum. Infeksi patogen ini dilaporkan dapat menyebabkan kerugian besar pada berbagai sentra produksi dan ancaman pada daerah target pengembangan di Indonesia.

Beberapa mikrob yang menyelimuti perakaran tanaman sehat diketahui sebagai pelindung dari serangan patogen layu. Pada perakaran tanaman sehat, bakteri antagonis Bacillus subtilis, Pseudomonas fluorescens dan Streptomyces sp. dilaporkan dapat mengendalikan $R$. solanacearum pada kentang (Nurbaya et al. 2011).

Kabupaten Tana Toraja memiliki potensi menjadi daerah pengembangan hortikultura, termasuk kentang. Eksplorasi keragaman bakteri rizosfer sangat diperlukan untuk mengetahui potensi ketersediaan agens hayati terhadap penyakit layu kentang. Penelitian dilakukan untuk mengevaluasi efektivitas beberapa isolat rizobakteri dan bahan organik untuk menekan penyakit layu kentang.

\section{BAHAN DAN METODE}

\section{Isolasi dan Perbanyakan Fusarium oxysporum dan Ralstonia solanacearum}

Isolat Fusarium diperoleh dari koleksi Laboratorium Bioteknologi, Universitas Hasanuddin yang telah diuji sebelumnya, sedangkan bakteri $R$. solanacearum diisolasi dari jaringan batang tanaman kentang yang memperlihatkan gejala layu. Jaringan diambil $1 \mathrm{~cm}$ lalu dipotong-potong hingga berukuran $5 \mathrm{~mm} \times 5 \mathrm{~mm}$ lalu digerus pada mortar hingga halus dan ditambahkan $1 \mathrm{~mL}$ akuades steril. Suspensi bakteri yang ada pada mortar diambil sebanyak $0.5 \mathrm{~mL}$ kemudian dimasukkan ke dalam tabung reaksi yang berisi $4.5 \mathrm{~mL}$
$\mathrm{MgSO}_{4} 7 \mathrm{H}_{2} \mathrm{O}$. Dari larutan tersebut kemudian diencerkan hingga mencapai pengenceran $10^{-6}$. Sebanyak $0.1 \mathrm{~mL}$ suspensi bakteri dari masing-masing tingkat pengenceran dipindahkan ke dalam cawan yang berisi medium spesifik untuk $R$. solanacearum, yaitu tetrazolium chloride agar (TTC) yang mengandung $10 \mathrm{~g}$ pepton, $5 \mathrm{~g}$ glukosa, $15 \mathrm{~g}$ agar, $1000 \mathrm{~mL}$ akuades, $8 \mathrm{~g}$ nutrient broth, dan 2,3,5-triphenyltetrazoliumchlorid (TTC) $1 \%$. Suspensi disebar merata pada seluruh permukaan medium dengan menggunakan spatula. Setelah 3-5 hari dilakukan pengamatan dan seleksi koloni bakteri yang khas kemudian ditumbuhkan kembali pada medium TTC yang baru.

Uji patogenesitas dilakukan melalui uji hipersensitivitas pada daun tembakau. Isolat yang telah murni selanjutnya dipindahkan ke media nutrient growth agar (3.3 g pepton, $2.7 \mathrm{~g}$ nutrient broth, $2 \mathrm{~g}$ ekstrak khamir, gliserol 2.5\% (v/v) dan $15 \mathrm{~g}$ agar-agar $\left.\mathrm{L}^{-1}\right)$ sebagai medium perbanyakan.

\section{Bakteri Antagonis}

Sampel untuk penelitian ini diperoleh dari rizosfer tanaman kentang, bambu, padi, terung belanda serta bahan organik kerbau belang dan babi di Desa Minanga, Kecamatan Mengkendek, Kabupaten Tana Toraja, Provinsi Sulawesi Selatan.

Sebanyak 1 g sampel rizosfer tanaman dan bahan organik disuspensikan dalam $10 \mathrm{~mL}$ air steril, lalu dibuat pengenceran hingga 6 kali. Pada pengenceran $10^{-4}, 10^{-5}$ dan $10^{-6}$, diambil sebanyak $1 \mathrm{~mL}$ dan ditumbuhkan pada medium King's B. Setelah murni, isolat diperbanyak pada medium agar-agar nutrien.

\section{Uji Kemampuan Daya Hambat Bakteri Antagonis terhadap $R$. solanacearum}

Isolat murni bakteri dari rizosfer dan bahan organik diinokulasikan pada botol berisi medium cair nutrien (8 g nutrient broth $\mathrm{L}^{-1}$ ), lalu digoyang dengan kecepatan $120 \mathrm{rpm}$ selama 3 hari. Setelah itu, sebanyak $1 \mathrm{~mL}$ medium cair dimasukkan ke tabung ependorf dan disentrifiugasi selama 10 menit dengan kecepatan $100 \mathrm{rpm}$. Supernatan selanjutnya 
disaring menggunakan filter $0.02 \mu \mathrm{M}$ dan dimasukkan ke tabung ependorf berisi larutan kloroform. Selanjutnya dilakukan pengenceran isolat murni bakteri patogen dan diratakan pada medium NGA. Kertas saring steril berukuran $0.5 \mathrm{~cm}$ dicelupkan ke dalam larutan kloroform yang mengandung supernatan bakteri antagonis, dikeringanginkan, lalu diletakkan pada bagian tengah medium yang telah berisi bakteri patogen. Pada perlakuan kontrol, potongan kertas saring dicelupkan dalam pelarut kloroform. Kemampuan antagonisme isolat-isolat bakteri terhadap $R$. solanacearum diukur berdasarkan diameter zona penghambatan disekeliling kertas saring.

\section{Uji Kemampuan Daya Hambat Bakteri} Antagonis terhadap Fusarium oxysporum

Uji kemampuan bakteri menghambat F. oxysporum dilakukan dengan metode kultur ganda Fokkema (1973). Persentase penghambatan $(\mathrm{P})$ dihitung dengan rumus:

$$
\mathrm{P}=\mathrm{Ro}-\frac{\mathrm{R} 1+\mathrm{R} 2}{2} \times 100 \% \text {, dengan }
$$

$\mathrm{R}_{\mathrm{O}}$, jari-jari pertumbuhan patogen pada perlakuan kontrol (cm); R1 dan R2, jari-jari pertumbuhan patogen pada perlakuan $(\mathrm{cm})$.

Penelitian ini disusun dalam acak lengkap dengan pengulangan sebanyak 3 kali pada setiap perlakuan. Analisis sidik ragam dilakukan, jika di antara perlakuan menunjukkan perbedaan yang nyata dengan uji Duncan pada taraf 5\%.

\section{HASIL}

\section{Isolat Bakteri dan Uji Antagonisme Terhadap $R$. solanacearum}

Dari rhizosfer tanaman kentang, padi, bambu dan terung belanda, serta dua jenis bahan oganik berhasil diisolasi sebanyak 74 isolat bakteri, yang terdiri atas 31 isolat dari rizosfer pertanaman dan 43 isolat dari bahan organik (Tabel 1).

Dari total 74 isolat bakteri yang diperoleh, 10 isolat bakteri memiliki potensi sebagai agens antagonis karena mampu membentuk zona hambat terbesar (Tabel 2). Isolat-isolat tersebut terdiri atas 1 isolat asal rizosfer, bambu dan 9 isolat asal bahan organik kerbau belang (Tabel 2).

\section{Uji Kemampuan Daya Hambat Bakteri Antagonis Terhadap Fusarium oxysporum}

Pengujian kemampuan daya hambat isolat-isolat bakteri terhadap $F$. oxysporum menunjukkan terdapat 4 isolat (BT5, KT9, KB11 dan KB25) yang memiliki kemampuan daya hambat tertinggi. Persentase daya hambat tertinggi $(80.68 \%)$ diperoleh dari perlakuan dengan isolat BT5, diikuti berturut-turut oleh KB11 (71.59\%), KT9 (67.41\%) dan KB25 (65.91\%) (Gambar 1).

\section{PEMBAHASAN}

Pengendalian hayati patogen menggunakan mikroorganisme yang berasosiasi dengan rizosfer dan bahan organik merupakan pendekatan yang efisien dan ramah lingkungan (Bargabus et al. 2003). Bahan organik bermanfaat sebagai nutrisi tanaman, dan mengandung sejumlah besar mikrob termasuk bakteri, cendawan dan kapang. Mikroba ini memecah residu organik menjadi senyawa yang lebih sederhana selama proses pengomposan. Peningkatan nutrisi ini meningkatkan jangkauan dan jumlah mikrob tanah, termasuk yang berpotensi sebagai agensia hayati terhadap patogen tanaman (Holguín-Castaño dan Mora-Delgado

Tabel 1 Hasil isolasi bakteri dari empat rhizosfer pertanaman dan dua jenis bahan organik

\begin{tabular}{lc} 
Sumber isolat bakteri & Jumlah isolat \\
\hline Rizosfer kentang (KT) & 12 \\
Rizosfer padi (PT) & 8 \\
Rizosfer bambu (BT) & 6 \\
Rizosfer terung & 5 \\
belanda (TB) & \\
Bahan organik & 8 \\
babi (BB) & \\
Bahan organik & 35 \\
Kerbau belang (KB) & \\
\hline
\end{tabular}


Tabel 2 Daya hambat isolat bakteri terhadap pertumbuhan Rolstania solanacearum secara invitro

\begin{tabular}{lccccc}
\hline \multirow{2}{*}{ Sumber isolat bakteri } & \multicolumn{5}{c}{$\begin{array}{c}\text { Jumlah isolat pada masing-masing } \\
\text { kategori daya hambat* }\end{array}$} \\
\cline { 2 - 6 } & - & + & ++ & +++ & ++++ \\
\hline Rizosfer kentang (KT) & 0 & 8 & 4 & 0 & - \\
Rizosfer padi (PT) & 0 & 2 & 4 & 2 & 0 \\
Rizosfer bambu (BT) & - & 3 & 1 & 1 & 1 \\
Rizosfer terung belanda (TB) & 1 & 4 & - & - & - \\
Bahan organik babi (BB) & 0 & 7 & - & 1 & - \\
Bahan organik kerbau belang (KB) & 0 & 19 & 4 & 3 & 9 \\
\hline Kenyyyyyy
\end{tabular}

Kemampuan daya hambat isolat bakteri dikelompokkan berdasarkan diamater zona hambat -, 0 (tidak ada penghambatan); -, 0; A, tidak ada penghambatan; $\mathrm{B}, 0.1-1 \mathrm{~cm} ; \mathrm{C},>1.0-2 \mathrm{~cm} ; \mathrm{D},>2.0-3 \mathrm{~cm} ; \mathrm{E},>3.0 \mathrm{~cm}$.

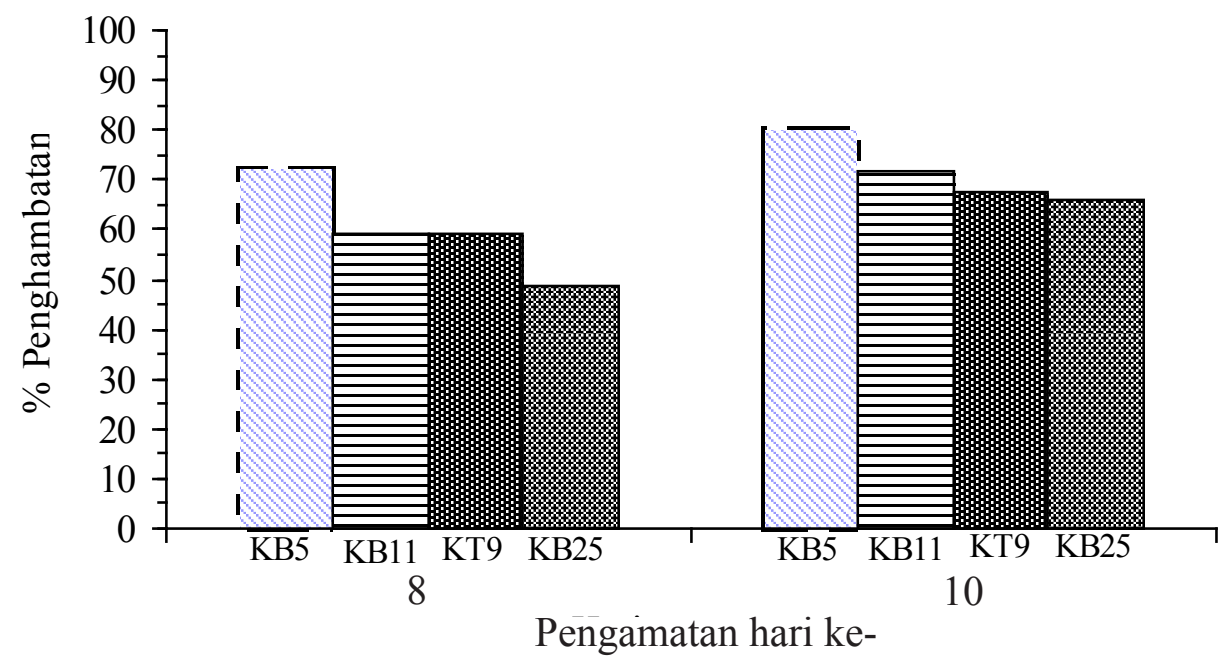

Gambar 1 Persentase penghambatan Fusarium oxysporum oleh 4 bakteri antagonis potensial (KB5, KB11, KT9 dan KB25) berdasarkan pengamatan pada hari ke-8 dan ke-10.

2009). Tahapan pengembangan agens hayati meliputi isolasi, skrining in vitro, uji kemampuan antagonisme, skrining in vivo, dan pengembangan formulasi (Ahmed et al. 2007).

Hasil penelitian menunjukkan bahwa isolat bakteri lebih banyak diperoleh dari bahan organik dibandingkan dengan dari rizosfer. Hal ini diduga akibat pengaruh struktur tanah, kesuburan tanah, kelembaban tanah dan ketersediaan nutrisi. Tanah yang sehat bukan hanya subur dan banyak mengandung bahan yang menunjang kesehatan tanaman, tetapi juga mampu menyediakan lingkungan yang cocok bagi mikrob tanah, sehingga tanaman dapat terlindungi dari patogen tanah (Nion dan Toyota 2008).

Dari total 74 isolat bakteri yang diuji hanya 10 yang memperlihatkan daya hambat terhadap $R$. solanacearum dan F. oxysporum, dan hambat terdapat 4 isolat yang memiliki daya hambat terbaik. Samia et al. (2013) melakukan skrining terhadap 111 galur bakteri yang berasal dari tanaman kentang dan gandum. Hanya 14 isolat bakteri dari tanaman kentang yang bersifat antagonis terhadap Phytophthora infestans, F. oxysporum $f$. sp. albedinis and $F$. solani var. coeruleum dengan persentase penghambatan mencapai $92.30 \%$. Tehrani dan Ramezani (2003) melaporkan 
bahwa kelompok rizobakteri yang merupakan mikrob antagonis adalah yang memiliki daya hambat diatas 51 persen terhadap patogen tular tanah seperti $F$. oxysporum Schlecht. Mikroba antagonis dapat berfungsi sebagai agens pengendali patogen melalui mekanisme kompetisi, antibiosis, parasitisme atau ketahanan yang terinduksi. Hingga saat ini kelompok bakteri yang paling banyak dimanfaatkan sebagai agens pengendali hayati adalah Pseudomonas berfluoresen (Weller et al. 2002) dan beberapa strain dari Bacillus (Choudhary dan Johri 2009).

Penggunaan agens antagonis untuk meningkatkan hasil panen dan melindungi tanaman dari serangan organisme penggangu tanaman merupakan pendekatan menjanjikan dalam sistem pertanian moderen. Penelitian terhadap isolat-isolat agens antagonis ini perlu dilakukan lebih lanjut untuk mengetahui mekanisme antagonistiknya.

\section{UCAPAN TERIMA KASIH}

Penelitian ini merupakan bagian dari tesis yang dibiayai oleh proyek Insentif Ristek TA 2012, Nomor Kontrak 06/M/Kp/I/2012.

\section{DAFTAR PUSTAKA}

Ahmed IH, Labuschagne N, Korsten L. 2007. Screening rhizobacteria for biological control of Fusarium root and crown rot of sorghum in Ethiopia. Biol Control. 40(1): 97-106. DOI: http://dx.doi.org/10.1016/j. biocontrol.2006.07.017.

Bargabus RL, Zidack NK, Sherwood JE, Jacobsen BJ. 2003. Oxidative burst elicited by Bacillus mycoides isolate, Bac J, a biological control agent, occurs independently of hypersensitive cell death in sugar beet. Mol Plant-Micro Interact. 16:1145-1153. DOI: http://dx.doi.org/10. 1094/MPMI.2003.16.12.1145.

Choudhary DK, Johri BN. 2009. Interactions of Bacillus spp. and plants - With special reference to induced systemic resistance (ISR). Microbiol Res. 64(5):493-513. DOI: http://dx.doi.org/10.1016/j.micres.2008. 08.007.

Fokkema NJ. 1973. The role of saprophytic fungi in antagonsim against Drechslera sorokiniana (Helminthosporium sativum) on agar plates and on rye leaves with pollen. Physiological Plant Pathology. 3:195-205. DOI: http://dx.doi.org/10.1016/0048-4059 (73)90082-9.

Holguin-Castaño VA, Mora-Delgado J. 2009. Dinámica microbiana en vermicompostas comerciales con y sin inoculación del hongo Trichoderma spp. Revista Luna Azul. 29:18-24.

Nion YA, Toyota K. 2008. Suppression of bacteria wilt and fusarium wilt by a Burkholderia nodosa strain isolated from Kalimantan soils, Indonesia. Microbes Environ. 23(2):134-141. DOI: http:// dx.doi.org/10.1264/jsme2.23.134.

Nurbaya, ZulfikarA, Kuswinanti T, Baharuddin dan Lologau BA. 2011. Kemampuan Mikroba Antagonis dalam Mengendalikan Ralstonia solanacearum pada Sistem Budi daya Aeroponik Tanaman Kentang. J Fitomedika. 7(3):155-158.

Samia MA, Nora H, Nadia S, Abdelhadi G and Mohamed MZ. 2013. Isolation and selection of indigenous bacterial strains with suppression properties from the Rhizospheres of potato and wheat. Annual Review \& Research in Biology. 3(4):405415.

TehraniAS. and Ramazani M. 2003. Biological control of Fusarium oxysporum, the causal agent of onion wilt by antagonistic bacteria. Comm Agr Appl Biol Sci. 68(4):543-547.

Weller DM, Raaijmakers JM, McSpadden GB, Thomashow LS. 2002. Microbial populations responsible for specific soil suppressiveness to plant pathogens. Annu Rev Phytopathol. 40:309-348. DOI: http:// dx.doi.org/10.1146/annurev.phyto.40. 030402.110010 . 